This item was submitted to Loughborough's Research Repository by the author.

Items in Figshare are protected by copyright, with all rights reserved, unless otherwise indicated.

\title{
Navigating the technology-media-movements complex
}

PLEASE CITE THE PUBLISHED VERSION

https://doi.org/10.1080/14742837.2017.1338943

\section{PUBLISHER}

(C) Taylor \& Francis (Routledge)

\section{VERSION}

AM (Accepted Manuscript)

\section{PUBLISHER STATEMENT}

This work is made available according to the conditions of the Creative Commons Attribution-NonCommercialNoDerivatives 4.0 International (CC BY-NC-ND 4.0) licence. Full details of this licence are available at: https://creativecommons.org/licenses/by-nc-nd/4.0/

\section{LICENCE}

CC BY-NC-ND 4.0

\section{REPOSITORY RECORD}

Fominaya, Cristina Flesher, and Kevin Gillan. 2019. "Navigating the Technology-media-movements Complex". figshare. https://hdl.handle.net/2134/33706. 


\title{
Navigating the Technology-Media-Movements Complex
}

Cristina Flesher Fominaya (University of Aberdeen)

Kevin Gillan (University of Manchester)

Note: This is the 'author accepted manuscript' version of an article accepted for publication in Social Movement Studies 16(4). The final an authoritative version is available at: http://www.tandfonline.com/toc/csms20

\begin{abstract}
In this article we develop the notion of the technology-media-movement complex (TMMC) as a fielddefinition statement for ongoing inquiry into the use of information and communication technologies (ICTs) in social and political movements. We consider the definitions and boundaries of the TMMC, arguing particularly for an historically-rooted conception of technological development that allows better integration of the different intellectual traditions that are currently focused on the same set of empirical phenomena. We then delineate two recurrent debates in the literature highlighting their contributions to emerging knowledge. The first debate concerns the divide between scholars who privilege media technologies, and see them as driving forces of movement dynamics, and those who privilege media practices over affordances. The second debate broadly opposes theorists who believe in the emancipatory potential of ICTs and those who highlight the ways they are used to repress social movements and grassroots mobilization. By mapping positions in these debates to the TMMC we identify and provide direction to three broad research areas which demand further consideration: (i) questions of power and agency in social movements; (ii) the relationships between, on the one hand, social movements and technology and media as politics ( i.e. cyberpolitics and technopolitics), and on the other, the quotidian and ubiquitous use of digital tools in a digital age; and (iii) the significance of digital divides that cut across and beyond social movements, particularly in the way such divisions may overlay existing power relations in movements. In conclusion, we delineate six challenges for profitable further research on the TMMC.
\end{abstract}

Keywords: Technology, media, ICTs, social movements, digital divides, cyberpolitics, technopolitics

Acknowledgements: We would particularly like to thank Graeme Hayes for insightful commentary on an earlier version of this article. 


\title{
Navigating the Technology-Media-Movements Complex
}

\author{
Cristina Flesher Fominaya and Kevin Gillan
}

The use of information and communication technologies (ICTs) in social and political movements is an ongoing and rich area of inquiry. Research work draws from several social scientific fields including movement scholarship, information and communications studies and media research. Our purpose in this article is to set out a general framework within which to navigate this field of inquiry. We begin by developing the notion of the technology-media-movement complex (TMMC) as a field-definition statement, allowing for better integration of the different intellectual traditions that are currently focused on the same set of empirical phenomena. We thereby introduce the essential features required for further rigorous knowledge generation in this area. In our first section we consider the definitions and boundaries of the TMMC, arguing particularly for an historicallyrooted conception of technological development and an approach to 'novelty' that recognises it as a continually reproduced feature of the TMMC, rather than as a technologically driven, momentary historical break. We describe potential routes for integration of approaches from various fields and disciplines -- including political communication, media studies, technology studies, organizational studies and social psychology -- whose insights can be fruitfully applied to analysis of the nexus between technology, media, and social movements. In the second section we delineate two recurrent debates. First, we examine the tension between accounts that privilege technology or social agency as drivers of social change, arguing that what has to be analysed is the interplay of collective processes, pre-existing political commitments, technological competences, and technical affordances. This approach recognizes the creative and strategic agency of social movement actors. Second, we outline debates between scholars who emphasize the emancipatory potential of digital technology and those who are much less sanguine about its liberating potential. We highlight the real insights that proponents of divergent positions have offered the field, but note the need for nuanced accounts of empirical reality to test the veracity of competing visions of digital futures.

In our third section we consider three areas of inquiry within the TMMC that merit further consideration. First, we consider differing conceptions of social movements and the implications of each position for navigating the TMMC, distinguishing between individual agglomerate, collective, and network analyses. Second, we consider the distinction between scholarship on social movements that engage with technology and media as politics (i.e. cyberpolitics and technopolitics) and those that focus on the quotidian and ubiquitous use of digital tools in a digital age, highlighting the need for more research on how these different understandings of the role of digital tools reciprocally influence each other in movement practice. Third, we examine the digital divide. Rather than seeing this simply as a matter of global inequalities of access to 
technology, we argue that complex forms of digitally-mediated exclusion exist within cyberspace and social movements and call for further research on the way these divisions overlay existing power relations on and offline. In this way we call attention to the need to pay more attention to lived experience and power in our analysis of the TMMC. In conclusion, we draw from the conceptual contributions of this article to set out six challenges for further research on the TMMC.

\section{Boundaries and definitions: technology, media, movements}

The study of ICTs and social movements is not (yet) an integrated subfield. There are two important reasons for the diffuse nature of inquiry in this area. The first is that empirically-led studies are often understandably interested in delineating the uptake of specific new technologies within social movements. Email, IRC channels, websites, pirate radio, mobile phones, live streaming, social media platforms; the list is potentially endless as new communicative technologies become available. From an empirical point of view one often wants to examine questions such as what ways are specific technologies put to use within particular movements, what they can contribute to mobilization or contestation, or what limitations might they place on actors. At this level, it is difficult to find broad applicability in answers to such questions. Differences in both underlying technological design and the political contexts in which they are adopted suggest that there is little hope that single cases will offer many general lessons without more concerted efforts at theoretical development. The result is that, for each technological innovation - now social media, previously, the Web, email, television and so on - there has been a tendency to cycle through a particular kind of unproductive debate: optimists see radical democratizing potential, pessimists see the reconfiguration of traditional power structures in a new arena, while others seek a middle ground.

A second barrier to integration in this area of inquiry is the fact that it necessarily draws on different fields. There is much productive potential in bringing these fields together, especially by combining insights from movement scholarship with those of (political) communication (Earl \& Garett, this issue), media studies (Mattoni, this issue) and technologies studies (Pavan, this issue). At present, however, it is more a case of separate lines of inquiry with only occasional intersections. As movement scholars writing in Social Movement Studies we, and several contributors to the issue, tend to examine ICTs through the conceptual frameworks developed in this field and address questions concerning the utility or otherwise provided in central movement processes such as the communication of movement frames, the generation of collective identities, or the production of movement resources. Nevertheless, we acknowledge that this movementcentrism is field-specific; elsewhere, Gillan has adopted frameworks drawing more from technology studies (2008) or political communication (Gibson et al, 2013), whereas Flesher Fominaya (2016) has drawn on insights from human-computer interaction studies and social-psychology to apply them to analysis of the TMMC. A vital first step in enabling positive cross-field developments is a more clearly defined statement of the particular complex of phenomena that has generated such a strong flow of research publications in recent years, namely: technology, media, and movements (or TMMC). We 
specify each in the following paragraphs.

For technology, ICTs are the core focus. It is these technologies in particular that have been the subject of so much innovation and excitement since the personal computers of the early 1960s, but especially since the creation of two major communication infrastructures: mobile phone networks beginning in the 1960s and the internet (and various nationally specific variants) in the 1980s. A technologically vital and more recent process here is widespread digitisation. Spurred by the characteristics of microchip processing and the internet, the more that data is available in digital form the more it can be transformed and communicated. This is not a trivial technological outcome. The first mobile phone networks, drawing from their obvious predecessors on landlines, were analogue communication systems and only became digitised with the 'second generation' EU-led GSM protocol deployed from the early 1990s, which not incidentally made short message service (SMS) texting feasible (Castells et al. 2006). Without the digitisation pathway, powerful and emotive imagery, audio and video would have been much harder to share online; and the visual language of contemporary information flows potentially changes the nature of the public sphere in which much movement communication is located (DeLuca and Peeples, 2002). Perhaps more fundamentally, without the digitisation of mobile networks the convergence between mobile phones and internet devices - creating complex hybrid spaces that intertwine the informational and the physical - would have been practically impossible (see De Souza e Silva 2006; Gordon 2006). From a communications angle, without decades of SMS texts it seems unlikely that many users would have found interaction through Twitter's 144-character messaging interface appealing or even coherent; the development of cultural competencies in ICT use is just as vital as technological affordances. It is the particular combination of internet and mobile infrastructures that is the source of a sense of the supposed 'ubiquity' of technologically-mediated communication, which we explore further below.

It is not all ICTs, then, but specifically those ICTs which enable rapid, low-cost networked communication among individuals that have been the vital technologies studied by scholars interested in the TMMC. Understanding the characteristics of the technologies involved is important; not because social outcomes are entirely technologically determined, of course, but because design characteristics create affordances that might or might not be adopted by thinking, feeling agents in specific circumstances. Here, insights from human-computer interaction studies and social psychological work on the experience of technology use are particularly helpful (e.g. Kiesler and Sproull 1992; Spears, Lea, and Corneliussen 2002; Lea and Spears 1991; Hargittai and Shafer 2006; Garton and Wellman 1995). Agentic processes are evident when, for instance, individuals and groups carry out interpretative work in examining the potential utility of affordances, and may even find ways of reshaping them (within limits) for purposes for which they were never intended (Himanen 2001; Gillan 2008). Yet such actions are hardly unconstrained: skill, time, and other resources are required to bring out the 'latent functionalities' of the technologies made available through (mostly) market means for (mostly) corporate ends (Gillan et al. 2008: 172-181). Further understanding of the role of ICTs in the TMMC may depend on making more use of social theories of technology in 
which a nuanced approach to both social agency and the political character of technological design are central (e.g. Feenberg 2002; Kirkpatrick 2008; Redshaw 2017; Pavan this issue).

Within the investigation of ICTs and movements, technologies are primarily of interest because of their role in mediating communication, hence the focus on media in the TMMC. From a pure technology studies approach, other developments may be more crucial. The invention of, for instance, the TCP/IP protocols (that manage the packaging, addressing, and transmission of digital data) enabled the construction of the internet on top of copper cables that had previously been intended for analogue telephone signals; this must count as one of the most significant hacks in history. Such protocols, and indeed the material hardware required (and usually privately owned), are potentially relevant 'mediators' of regular communication (Lessig 2002). For our concerns, however, such developments are mostly mere background, too far from the practicalities of mediated communication to have much obvious relevance. Thus technology is primarily of interest in its interrelationship with 'media' in our conception of the TMMC.

There are two senses in which 'media' can be rendered here. The first refers to the insertion of the ICTs delineated above into movement-relevant communications. The specific characteristics of communication as mediated by particular technological infrastructures presents challenges and limitations for social movement groups as is found by various studies of the affordances of such mediation (Flesher Fominaya 2016; Tufekci 2014a; Milan 2015; Gillan 2009; Wall 2007). The term 'new media' has been adopted in many studies to refer to this collection of technological innovations, defined through the following characteristics: their hybrid or recombinant formations, bringing together pre-existing technologies in a range of innovative ways; their contribution to the development of communication systems as 'reorganizing, unfolding [...] networks of networks' structured centrally on hyperlinks; and their enabling of on-demand access to information (Lievrouw 2011:8-16). The result is a sense of 'ubiquity' of information via new media, seemingly offering users 'an unprecedented degree of selectivity and reach in their choices of information and cultural resources and their personal interactions and expressions' (ibid). So defined, the term 'new media' remains a useful referent point because it is general enough to encompass both the 'older' web technologies (e.g. email, websites, blogs) and the growing raft of new applications of new media information networks (e.g. social media, live streaming) that come along as mobile devices with expanded capabilities and near-permanent internet access have been more widely adopted (see also Siapera 2012).

The notion of 'newness' is worth further consideration. As Lievrouw and others have indicated, there is genuine novelty to the forms of communication network now in wide use. But there is also a tendency to fixate on the newest formations capturing the imagination of technology enthusiasts. This can lead to a form of 'myopia of the present' (Melucci 1994) which doesn't situate media technology use within a longer term perspective, and can ignore the ways that newer media forms evolve from previous forms and practice. It also leads to a form of presentism that fails to acknowledge the dynamic nature of technological advances in which particular platforms and their affordances - 
however important they might be now - may soon become modified, obsolete, or replaced by other forms of media; or conversely how platforms used only by specialized activists today may become widespread tomorrow. The myopia of the present, therefore, doesn't just relate to the past but to the future. Thus we need to be able to resist the tendency to see each technological development as radically new, as this makes it difficult to spot underlying commonalities in the nature of communications, technological adoptions, agencies, and power.

We do not make this point to deny the novelty of new media. Indeed, over recent decades we have seen changes in communication, self-expression, collective identity formation, personal network building, and activist communications strategies as a result of the increasingly digitally-mediated nature of the everyday lives of increasing numbers of people. However, one could not define a single innovation or a single moment at which there is a distinct break from the past (see also Ganesh and Stohl 2013); instead we see the sometimes-fast, sometimes-slow build-up of new forms of technology alongside, crucially, the cultural competencies, practices, and preferences required to make sense and use of them (e.g. Costanza-Chock 2012). The novelty of 'new media' is thus less about a moment of change (and therefore is not a clear distinction between old and new) and much more about the fact that the production of novelties is now built into a system that is defined, as noted above, by the construction of hybrid and recombinant technological formations. Much as Daniel Bell (1974) noted the importance of planned research and development in corporate infrastructures in the changing timescale of innovation in business, we can see that today we have a networked information infrastructure that results in rapid, repeated moments of innovation that can change the characteristics and uses of the network itself.

'Media' in the TMMC thus refers in one sense to the role of technological mediation in communication between individuals and groups that make movements happen. But there is also a second, more general, sense in which 'media' is vital. This refers to the institutions of traditional news media (sometimes erroneously referred to as 'old media') - whether distributed via newspapers, television or the internet - through which all political actors gain key information. This is a significant point of intersection with the field of political communications (Earl \& Garett, this issue) as well as media studies (Mattoni, this issue). The importance for social movements of finding representation in dominant news media outlets has long been studied, especially among those interested in processes of interpretative framing (Ryan 1991; Smith et al. 2001; e.g. McCarthy, Smith, and Zald 1996; Oliver and Maney 2000; Gitlin 2003). ${ }^{1}$ The more recent entanglement between news media and the 'new media' generated by the technological developments indicated above, however, complicate simple models of movement groups as 'outsiders' trying to gain entry to a hegemonic news agenda. In addition to our analyses of the mediated nature of group communication per se, therefore, we need to maintain an analytic gaze on the ongoing influence of those institutions which generate, select, frame,

${ }^{1}$ For an overview of the relation between mass media and social movements, see Flesher Fominaya 2014, Ch. 6 
and disseminate 'the news'. Those institutions are often significantly controlled by state agencies or megalithic corporations and are now very large presences in 'new media' too, both in terms of size of websites and user traffic. Nevertheless, in the contemporary 'media ecology' (Mattoni, this issue; 2012) they become increasingly integrated with other circuits of information diffusion, especially those that present themselves as neutral 'platforms' (Gillespie 2010), potentially making for a more responsive and diverse (if rather cacophonous) information environment. The apparent influence of 'alternative' news sources such as Breitbart in the recent US Presidential Election campaign and the related fears that we now live in a world of 'post-truth politics' are clear indicators of the potential for surprise extant in this complex information environment.

We have thus far bounded the TMMC by specifying the relationship between particular ICTs and their role in mediation - both of communication within networks and in their role in constituting the wider media ecology. The final boundary-drawing task is thus to specify how these connect with social movements. While we do not wish to get fully entangled in the 'what is a social movement?' question here (for some direct answers see Johnston 2014), in defining the TMMC it is necessary to offer some definitional clarity. For us, the definitional features of 'social movement' must minimally include a degree collectivity through voluntary coordination of activity in the pursuit of values or interests that produce conflict with other social actors (Gillan forthcoming). The processes by which individuals come together, recognise common experiences of social problems, develop diagnoses of those problems, and begin to form strategies to attempt to overcome them remain, in our view, inherently collective. To identify a social movement is to prioritise processes that are inherently, and largely intentionally, collective in nature. The division between more individual and more collective approaches to the TMMC highlights a significant analytical question to which we return in the next section.

We have so far defined the core elements of the TMMC, identifying the empirical phenomena of interest by considering the intersection of technology, media, and movements. In doing so, we have highlighted especially the need to draw on insights from fields beyond our immediate frames of reference as social movement scholars. This approach is likely to yield fruitful analyses of the crucial puzzles and challenges facing social movements and scholars today. By arguing against a 'myopia of the present' we present a vision of novelty that is not the result of a particular historical break, but rather a result of varying combinations of movement action, media work, and technological play which enable the dynamic complexity of the TMMC; the tendency to reification of novelty is rendered as problematic. We now move on to consider two core analytical debates and approaches to the TMMC, before considering three vital areas for further research.

\section{Core Debates on the TMMC}

By defining the TMMC above, we offered some descriptive boundaries of the empirical phenomena of interest to those working under the broad heading of 'ICTs and movements'. We now outline two recurrent core debates: the first between those who privilege either technology or social agency as drivers of mobilization; and the second 
between those who privilege the emancipatory versus repressive potentials of ICTs.

\section{Technologically or Socially-driven Changes?}

While most scholars are sensitive to critiques of technological determinism, there is a continuum within the field from scholars who tend to privilege technologies and see them as driving forces of movements, among other major dynamics (e.g. Rheingold 1993, Shirky 2009; Benkler 2006; Bennett and Segerberg 2013), to those that keep their focus on social actors and the ways that they deploy these technologies, through privileging media practices over affordances (see Mattoni, this issue; Mattoni 2012, Flesher Fominaya 2014). It is undeniable that the advent of cyberspace has created an arena encompassing significant new elements in the forms and consequences of political communication, political engagement, and political conflict. Simultaneously, it is impossible to see these developments as a singular causal force in the production of movement mobilization or outcomes. Castells argues that online social networks are 'tools at the disposal of any individual or self-created network of individuals who want to have their views aired ... the diffusion of Internet-based social networks is a necessary condition for the existence of these new social movements in our time. But it is not a sufficient condition' (Castells 2015: 226). Castells makes this point specifically for the category of 'new networked social movements', which emerges from his analysis of the post-2010 movements; he rightly recognises that there are other forms of movement for which particular technologies cannot be considered a necessary condition.

Given that neither technology nor any single actor can be understood as sole driving force in the TMMC, what has to be specified is the interplay of collective processes, pre-existing political commitments, technological competencies, and technical affordances, in which it becomes possible to recognize the creative and strategic agency of social movement actors. Two examples illuminate this point. Firstly, Bitcoin is an alternative currency based on the coming together of several key advances in highly complex uses of network technologies. The 'mining' of Bitcoin is built into the technological design as an incentive structure in which early adopters were able to receive currency by running fast computers to solve complex mathematical problems that served the needs of the network. A designed-in reduction of the rate of currency growth means that eventually the energy costs of running mining software would outstrip the value of the mined coins (Redshaw 2017: 55-6). That is to say, technological adeptness combined with access to material resources allowed the production of wealth for a clique of interested parties. As Redshaw (2017) reveals, a libertarian attitude drawn from 'cypherpunks' was embedded in the purpose and design of the technology from the start. While this has been contested during technical development, there was a neatness of fit between libertarian technological design and the rising interest in Bitcoin from people whose ideological commitment was to a Hayekian 'denationalization of money'. This demonstrates: firstly, that the exercise of technological agency need not be democratic in nature; secondly, that the significance of Bitcoin can only be understood in relation to cultural preferences and practices alongside technological competence and material capability. 
A second example of technological-social interplay comes from Uitermark's study of Anonymous (this issue) in which access to and adeptness with particular technologies are characteristics that shape power dynamics within that group; a form of internal digital divide that we explore further below. Because Uitermark's approach is ethnographic he is able to see beyond the characteristics of communication shaped by technological design to the social forces at play in generating power structures among a nominally horizontally-organised and leaderless group. We see some mirroring of the long-known 'tyranny of structurelessness' (Freeman 1972) here, but also other characteristics - such as the problematically 'thin' degree of shared political identity - that must finally be understood as shaped by location of Anonymous within the TMMC. In other words, specific technologies shape the precise form these power plays manifest, but the dynamics they reflect echo longstanding social movement conflicts and challenges.

Both examples suggest that there is nothing inherently progressive or democratic about technologies, such qualities are only made manifest in the use to which they are put, and even the best intentions can lead to unintended consequences; this insight underlies our position on the next recurrent debate within scholarship on the TMMC.

\section{Emancipation and Repression}

Scholarly debate has distinguished theorists who believe in the emancipatory potential of new ICTs from those who are much less sanguine about their possibilities and who highlight the ways that political and economic elites and the state use these technologies to control, surveil, and limit the power of social movements and grassroots mobilization. 'Techno-utopianism' was a feature of rising initial excitement as new ICTs became widespread, with Rheingold (1993:14) defining the political significance of ICTs as lying in their 'capacity to challenge the existing political hierarchies' monopoly on powerful communications media, and perhaps has revitalized citizen-based democracy' (also Shirky 2009; Benkler 2006). The idea that the architecture of internet communication carries inherent democratic potential is now widely seen as naive (and is countered by our two examples above), but opposing this with a 'techno-pessimism' or 'cyberskepticism' would be similarly over-simplistic, and simply 'contribute further ammunition to the tiresome binary debate' (Dencik and Leistert 2015: 2). In fact, it is only logically possible to come to a pure 'techno-utopian' or 'cyber-skeptic' position on the basis of a uni-causal technological determinism; otherwise social processes of interpretation, interaction, the exercise of power and identity formation will inevitably confound the theorists' predictions. The questions for analyses of the TMMC are instead, therefore, in what ways might the interplay of technological development and social action achieve democratic visions, and in what ways does it produce barriers through repression?

Morozov (2011) argues that while the Internet can serve a democratic function, not enough attention is being paid to how states have used it as a tool of repression and control; nor how much of the cutting-edge research used to develop tools such as face recognition software, sophisticated user content analysis, and social media analysis has 
been harnessed by governments to repress and censor dissidents, and control citizen access to online content. Margolis and Resnick (2000) argue that political players with power in 'the real world' (offline) can also gain the upper hand in cyberspace. Tufekci (2015) further alerts us to the ways that corporate owned social media poses significant risks to democracy, including electoral processes, through their ability to modify their algorithms to manipulate and bias information that users see. The extent to which these corporate 'psycho technologies' can be used to manipulate not only users' impressions but also their emotions, allied to the opacity of data mining practices and its uses by corporate platform owners, suggests a need to pay increased attention to the negative implications for social movement actors (see e.g. Leistert 2015).

The increasing reliance on corporate-controlled spaces for activist communication raises critical questions for movements working against neoliberal global capitalism or who are committed to critiquing and contesting political and economic elites (Hintz 2015). The dangers posed by public discussions, organizations, and networks being observed, monitored, archived, and censored by corporate enterprises has serious implications for cyber activism and for social movement organizing online (Askanius and Gustafson 2010, Flesher Fominaya 2014). Stoycheff and Nisbet discuss the ways in which authoritarian governments not only restrict internet freedoms, particularly to political content, but also establish "psychological firewalls" that paint the internet as a scary world full of political threats. This rationale increases threat perceptions among the public. This, in turn, increases the public's support for online political censorship' (2016: n.p.). The authors highlight the limitations of techno-deterministic narratives that assume technological affordances will shape use: as they argue, we need to dispense once and for all with 'the "if we build it, they will come" philosophy underlying a great deal of internet freedom promotion [that] doesn't take into account basic human psychology in which entertainment choices are preferred over news and attitudes toward the internet determine its use, not the technology itself' (ibid.) Remembering too that media-based tactics such as political culture jamming are not limited to progressive radical grassroots social movements but can be used by political and social movement actors on any point of the spectrum, as well as by political parties and corporate actors, acts as a corrective to overly optimistic narratives about the emancipatory potential of new media.

Whistleblowing projects like Wikileaks and Xnet have demonstrated the capacity for small organized groups to pose significant challenges to powerful elites and states. The recent examples of the role of 'fake news' and hacking exposés in the Clinton/Trump electoral race, however, show that drawing a neat distinction between elites and grassroots actors is not simple, and the debate over the legitimacy of Wikileaks, an influential and at times widely admired group, shows how complex disentangling 'sides' top/bottom, us/them, progressive/reactionary - and motives can be (see also Gallo-Cruz 2016). What is clear is that any analysis of ICTs and social movements needs to be aware that the political cultures tied to internet use matter, and that the state can and does play an important role in structuring a context which can foster or prevent movements' ability to use ICTs effectively. Rather than situate themselves on one side or the other of this debate, most scholars now recognize the tension between emancipatory and repressive 
tendencies, a tension inherent in the network architecture of digital communication itself (e.g. Castells, 2009, 2012 Dencik and Leistert, 2015, Jordan 2015, Lievrouw 2011).

\section{Power, Politics and Agency in the Digital Age}

We have thus far described two continua on which current debates around the TMMC can be organised. These positions are likely shaped, but not necessarily determined, by the pre-existing ontological and epistemological commitments or methodological choices which underpin them (on which more below). We have argued that in navigating the TMMC we must understand new technologies as always (and already) enmeshed within social processes. Neither technological design, nor decisions on adoption, can float freely of the actors participating in those processes. From that position it is only logical to understand the potential for either emancipatory or repressive outcomes as continuously unfolding and contested, a matter for empirical evaluation rather than theoretical fiat or rhetorical pronouncement. From this position, we now detail three areas in which further scholarly work is required for a better understanding of the interplay of technological and social processes in the TMMC: 1) attempts to embed both individual action and collectives within a socio-political context alive to power relations; 2) differentiation of 'cyberpolitics' and its influence (or otherwise) from quotidian ICT use; and 3) understanding the ongoing relevance of digital divides and dimensions of power on social movements.

\section{Individuals, Collectives, Networks}

Some scholars approach social movements as an agglomeration of individual behaviours. To some extent this follows in the footsteps of Olson's (1965) seminal treatment of collective action: reducing it to the behaviours and preferences of rational individuals highlights the need for cooperation in formal institutions to overcome the free rider problem. Here, there is an ease of fit between the aggregation of individual action and the methodological possibilities enabled by access to social media data, since that data is generally interpreted at the level of the individual (albeit located in networks of interaction). Thus predictive-explanatory models, sometimes with experimental designs, analyse online individual behaviour in order to explain mobilization without recourse to direct observation of, or contact with, mobilizing groups (but see Mercea and Yilmaz 2017 for an alternative social learning process based on formal modelling of individual actions).

Margetts and John (2015), for example, use experimental data to analyse and predict the role of social media in mass mobilizations, like Spain's 15-M or Egypt's Revolution. A core part of the data that shapes their model comes from online petitions, although that form of action cannot be reliably used to predict or explain other forms of mobilization (e.g. high risk protest where issues of trust, solidarity, and emotion work are brought to bear on individual decisions to participate). From these formal models and experimental designs they argue that social media enables 'mobilizations without leaders, revolutions without organizations' in line with arguments put forward by Bennett and Segerberg 
(2013). Bennett and Segerberg furthermore link the advent of social media use to an increase in individualization in society, thereby aligning method and theory. In these approaches, contextual factors are treated as less important than individual actions (petition signing, voting, clicking, liking, sharing, and so on), or else context is seen as influencing individual rather than collective behaviour (e.g. Hwang et al. 2006; Brym et al. 2014).

In contrast to work adopting a summative individual agglomeration model of action, scholars adopting a collective action approach see social movements as necessarily involving meaningful and extended collective processes of interaction and reciprocal engagement of groups of people tied together in networks or fields of action. Such approaches are more likely to understand ICT adoption in movements as shaped by specific media ecologies, cultural repertoires, collective ideational frameworks, and subject to the dynamics of collective decision-making, including political communication strategies, protocols, and ethics (e.g. Mattoni, this issue; Hensby this issue; Flesher Fominaya 2016; Kavada 2015, 2009; Firer-Blaess 2016; Coleman 2010, 2012; Milan 2013). Scholars working from this point of departure often require methodologies that involve qualitative engagement with, or observation of, internal movement processes and dynamics. Whereas the former approach focuses primarily or exclusively on mobilization (often of low cost activities), the latter see this as only one part of what social movements do and extend analysis of media use to internal organizational and communication processes as well as external ones.

The relevance of socio-political context becomes particularly salient when analyzing collective processes, whether enacted online or off. In work on the TMMC, that context whether theorised as a relatively static opportunity structure or something more dynamic - is heavily shaped by the shifting landscape of technology and media described above, potentially reflecting back on the nature of collectives created (Dolata \& Schrape 2016). As Mattoni (this issue) highlights, a media ecology approach recognizes not only the complexity of media use by movements (i.e. the full range of media practices and the cultural and political rationales that drive them) but also the wider media context within which they operate. This wider media context is itself open to modification by social movement actors themselves, especially those engaged in critical media practices: for example, as Flesher Fominaya's research shows,2 Spain's 15-M movement not only effectively mobilized multiple digital media tools, but provided a support base and impetus for the development of various critical media initiatives that attempted to put into practice alternative media business models (based on collective ownership, subscriptions and crowd funding). While some such initiatives existed prior to 15-M (e.g. critical collectively produced newspaper Diagonal), the supply of and demand for independent critical media increased in a virtuous circle, with mobilization enabling the

2 Marie Sklodowska-Curie Research Project 'Contentious Politics in an Age of Austerity: A comparative study of anti-austerity protests in Spain and Ireland' (2013-2015). This research involved extensive participant observation, over 70 interviews and secondary data analysis. 
emergence of independent critical 'mass' media, thus altering the media ecology of political communication in Spain in significant ways (see also Casero-Ripollés and Feenstra 2012). The new independent, largely worker-owned, critical media consortium 'El Salto', for example, has significant implications for social movement communication (in that the consortium is committed to covering issues related to progressive social movements), but also represents a radical media movement process in and of itself. Improving understanding of the dynamic interplay between different but overlapping movement groups and their 'contexts' is vital, then, and more likely to emerge from analytical perspectives that begin with a critical approach to the construction of movements as collectives.

The division we have set out between more individualist and more collective units of analysis is often reflective of background ontological positions and methodological choices, but this is not necessarily an insuperable dualism. Two directions for further thought emerge from the contributions to this volume. Firstly, Ahmed et al. take an interesting step in analysing the emotional valence of tweets surrounding the Nirbhaya movement reacting to a gang-rape incident in Delhi. Here they code tweets for the sense of 'individualism' or 'collectivism' portrayed in the text. Thus the degree of collectivism experienced in the movement becomes an empirical question for analysis rather than a matter of theoretical standpoint. Secondly, Uitermark utilises complexity theory in his investigation of Anonymous, allowing a nuanced account of the development of power structures in an especially individualised and supposedly horizontal forum. While Uitermark argues that movements are agglomerates beyond the control of any individual or group, he also argues that they are defined by their capacity to self-organize and are essentially 'generative, creative and transgressive'. Complexity theory potentially offers a way of understanding collective activity as emergent from relational processes among individuals (c.f. Chesters \& Welsh 2006). Again, one might start from the need to empirically examine degrees of collectivity to understand the ways in which emergence might operate in the TMMC. Anonymous is perhaps at the boundaries of what one might consider a 'movement' in any traditional sense and that makes questions about the relationship between the individual and collective especially sharp. Similarly, studies that begin with social media activity or other communicative media may end up examining primarily activity that is connected, but not necessarily central to, the traditional 'stuff' of movements. These insights are pertinent to continue thinking through what is at stake in taking particular sets of individual practices as indicative of social movements per se.

A further way to overcome the danger of a dualism between more individualistic or more collectivist approaches lies in a focus on networks and the relationships of which they are composed. While formal network analyses have become increasingly popular in social movement scholarship more broadly (e.g. Diani and McAdam 2003; Krinsky and Crossley 2014), the network approach becomes most obviously relevant to the TMMC through Castells' (1996) conception of the network society. This opens up questions of power and culture that are especially significant. Castells has argued that power is exercised through networks in a number of ways: controlling access to, or exclusion from, particular networks; programming the purpose of networks; or controlling the connections 
between multiple networks (Castells 2009: 42-7). Resistance takes the form of generating counter-power through networks by the same means, but it is precisely in the interconnection of the ICT and media trends that we described as central to the TMMC that movement actors gain the possibility for new forms of contestation (Castells 2009: 47-53). It is, for Castells, the capacity for 'mass self-communication' - enabled by and intersecting with new media ecologies and digitization processes - that allows the generation of counter-power by global social movements (2015).

Two elements are missing from this conception of power, however. First, we need a stronger recognition of the ways in which communicational power is shaped by other relations of power. Below, we briefly outline the ways in which the continuation of digital divides on the lines of gender, age, ethnicity, and class overlay 'traditional' power structures. Second, within Castells' account of communicational power, the degree to which engaging (or refusing to engage) in mass self-communication ought to be understood as a cultural preference rooted in the cognitive and emotional characteristics of actors is curiously absent. Castells has occasionally been accused of technological determinism, although as we have already noted we do not think that charge is pertinent here. Nevertheless, if we wish to understand the operation of power in the TMMC we need to delineate the sources of preferences for engaging power in these ways, which are likely to be rooted in cultural formations, whether these are understood as ideologies, interpretative frames, collective identities, or discourses. This approach is usefully highlighted in work on the social forum movements in which it was clear that a 'cultural logic of networking' was a developing political and strategic preference among many participants (Juris 2008; Pleyers 2011). Further investigation of intertwining cultural formations and power structures is vital to a fuller understanding of the TMMC.

\section{From Cyberpolitics to Quotidian Technologies}

The development of new media and the internet has created new fields of contention over the governance of communication networks, the production of software, access to information and indeed the fundamentals of technological design (Jordan 2002, 2015; Kirkpatrick 2011). The creation of these new tools has inspired, and been inspired by, new forms of activism (Flesher Fominaya 2014: 135-137; Stalder 2010). An important but not always explicit distinction in TMMC scholarship is that between the explicitly political use of digital tools in cyber and techno-political movements, and the increasingly ubiquitous and quotidian use of these tools in social movements in general. We use the term cyberpolitical movements to refer to movements who take the virtual arena as the central focus and purpose of their mobilization.

Cyberpolitics can take many forms. At times, the focus is on technologically-mediated forms of action. The 'hacktivism' of early pioneers like the Electrohippies has its echoes in more recent groups such as Anonymous. Additionally, the creation of alternative citizen media of all kinds, digital guerilla communications advances, culture jamming, and whistleblowing (Baker \& Blaagaard, 2016; Castells et al. 2006: 202-6; Carty, 2002; Coleman 2015) all offer forms of action dependent on digital savvy that could potentially 
be applied with a wide range of political motives. More often, however, these techniques are used in connection with a cyberpolitical perspective in which movements are ideologically and practically committed to harnessing the emancipatory power of ICTs, and see cyberspace as a primary site of contention and mobilization. The development of a specific politics of information that is tied to the age of the internet has a number of important expressions in broader movements for 'free culture', free and open source software (F/OSS) and attempts to create and preserve a digital commons (Fuster Morell 2012; Lessig 2002; Coleman 2012; Stalder 2010). The development of Pirate Parties in a number of European countries, and their success in Iceland (in which the Pirate Party is currently the third largest party) is instructive here (Leruth 2016). Standing on platforms centred on civic rights, information freedom, privacy, transparency, and a radically critical stance on copyright and patent laws, their main concerns mirror the cyberpolitics found in the kinds of movements noted above. They tend to carry too a (broadly libertarian) critique of representative democracy, arguing for the development of new technologically mediated forms of deliberation (Cammaerts 2015). This might help explain the particular popularity of the Icelandic Pirate Party, after an experimental, postcrisis 'crowd-sourced' constitutional process gained widespread participation (Oddsdóttir 2014).

The development of both new tactical or strategic possibilities and a new discourse of information politics is clearly a significant aspect of the developing TMMC. There is some connection here with the 'hacker ethic', the influence of which has been ethnographically explored among a range of groups from F/OSS programmers (Coleman 2012) to anti-war activists (Gillan 2008). We do not suggest either that the hacker ethic determines the content of cyberpolitics, nor that it is everywhere the same. In Spain, for instance, the subfield of tecnopolitica or technopolitics exists as an activist and academic category that interrogates the nexus between digital imaginaries, digital technologies, and political action in social movements (Subirats et al. 2014; Monterde and Postill 2014; Blanco and Duarte 2011; Romanos and Sádaba 2015; Postill 2014, Casero-Ripollés and Feenstra 2012, Feenstra and Casero-Ripollés 2014). Here we would expect a different political tilt to that described by Coleman (2012) for (mainly) US-based programmers, although the combination of political action with digitally-inscribed imaginaries is itself a common trait (Boler 2010; Coleman 2015; Jordan 2013, Pickerill 2003; Stalder 2010).

The ideological components of cyberpolitics are enmeshed in wider ranging movement politics. Postill (2014), for example, points out the importance of various kinds of 'freedom technologists' (from programmers to lawyers and journalists) in the development of 15-M. If we only look at those groups, however, it is tempting to read 15$\mathrm{M}$ as overly influenced by cyberpolitics, when of course its ideological and strategic characteristics drew from pre-existing movement cultures, the political history of Spain as well as the particular experience of economic crisis in that country (Flesher Fominaya $2015,2017)$. We think it likely that there is a multidirectional influence in terms of ideological and discursive resources as cyberpolitics bleeds into other movement spaces. Commitment to some of the values connected with the cyberpolitical realm can be evident without necessarily seeing the use of complex technologies. For example, activists 
might recognize the strategic benefits of corporate owned social media but reject its use on ethical grounds (see Askanius and Gustafson 2010, Flesher Fominaya 2014). Likewise, some activist groups develop technical protocols for online political communication that include prohibitions on the circulation of news from corporate owned media sources. These ideological frameworks can lead groups sometimes to deliberately eschew more technologically sophisticated forms of action for ethical or strategic reasons (see Lievrouw 2011:173 - 174).

Beyond cyberpolitics, the adoption of ICTs in movements may take many forms. Because digital technologies and media have also become a quotidian feature of so many people's lives, understanding how activists navigate the TMMC in movements who do not prioritize the digital and virtual as political is equally important. Scholars have increasingly studied the use of ICTs as a quotidian and ubiquitous aspect of social movement communication processes across a wide range of issues not directly related to digital media and the politics of cyberspace, as well as its use and importance during episodes of mobilization by actors without specialized technical skills (e.g. Flesher Fominaya 2016; Tufekci and Wilson 2012; Ganesh and Stohl 2013; Milan 2013; Kavada 2009; Fernandez-Planells, Figueras-Maz, and Pàmpols 2014, Nielsen 2013). Ganesh and Stohl (2013) describe digital media ubiquity in Occupy Wellington, in which activists drew on multiple digital sources of information, and activists' personal networks were intricately embedded in digital media use. As Mattoni (this issue) and Nielsen (2011) argue, we still know relatively little about the relationships between the routine use of digital tools and political agency in citizens' decisions to join or participate in movements or politics. Liu (this issue) offers an analysis of the mundane digital media use in everyday resistance in China, and like Nielsen (2011) and Ganesh and Stohl (2013), highlights the deep integration of such use into recruiting and mobilizing practices. An adequate understanding of the TMMC clearly needs both kinds of research focus. Additionally, the degree to which cyberpolitics influences or is influenced by the everyday use of ICTs in social movements is another potentially fruitful area of inquiry. The role of hackers and cyber-activists in the recent wave of Occupy type movements is, for instance, understudied (but see Romanos and Sádaba 2015), with most scholars focusing on the ubiquitous/quotidian elements of digital media use (e.g. FernandezPlanells, Figueras-Maz, and Pàmpols 2014; Ganesh and Stohl 2013).

\section{Exclusions and divisions in the age of new media}

Claims that new media use is 'ubiquitous' in some sectors of the population need to be tempered by an awareness of the continuing existence of digital divides that cut across social movements. This has implications for research methods as well as for the evaluation of the causes, dynamics, and impacts of new media use for social movements. If 'ubiquity' is understood as ICT use spreading across whole societies, it is highly misleading and needs to be interrogated. In the UK, for example, Ofcom's report on media literacy noted that $13 \%$ of adults do not use the internet at all (Ofcom 2016: 23-5). Nonusage is clearly patterned by age, with $33 \%$ of over 65 s (rising to $65 \%$ of over $75 \mathrm{~s}$ ) reporting that they never use the internet. Volume of internet use is also patterned: 
younger, wealthier people on average spend much longer online than older or poorer people and engage in a wider variety of activities (Ofcom 2016: 23-5). Around 70\% of internet users in the UK have a social media profile, which usually means Facebook. While Twitter has become an incredibly popular research tool, it is a relatively peculiar pastime. In comparing Twitter use in the UK and US, Blank (2016) finds that not only are Twitter users in both countries younger and wealthier than other internet users (and hence even more so compared with the wider population), but they are more likely to be members of elites and have characteristically different attitudes and behaviours than the wider populations.

Moreover, while British and American Twitter users share some characteristics, there are cross-country differences too, especially pertaining to ethnicity. Not only do Twitter users not represent the wider population, but different national Twitter populations cannot be taken as representative of each other. These insights have important implications for social movement research using social media data. To take one example: the importance of 'hashtag activism' to the development of Black Lives Matter in the USA has been widely discussed in terms of its temporalities, its capacity to enable the emergence of a public counter-discourse, and its creation of solidarities (Bonilla and Rosa 2015, Freelon, Mcllwain and Clark 2016, Jackson and Welles 2016). From a TMMC perspective, however, what is consequential here is that \#BLM did not spring from a virtual or decontextualised tabula rasa, but rather from a specific set of patterned relationships between black subcultures, mainstream media practices, and social media use. Blacks in the USA are disproportionately high users of Twitter, to the extent that we can talk of the emergence of a 'Black Twitter', fuelled by the technological development of hashtags and trending topics on the Twitter interface. Brock (2012) accordingly positions twitter as a cultural rather than social network, in which hashtags operate simultaneously as sign, signifier and signified, particularly through their performative structuring as 'call-and response' by Black Twitter users. The Twitter interface thus indirectly enables Black interventions into White public space.

Only when we grasp the interplay between these elements can we avoid the pitfalls of what Melucci (1994) calls 'the myopia of the visible', namely the tendency to focus on the most visible and easily measured aspects of mobilization, while neglecting the cultural codes and practices that generate them. The methodological point is that studying online participation exclusively cannot tell us anything about non-participation; it only captures the behaviour of those who are already participating (Flesher Fominaya 2016, Tufekci 2014a). This makes it harder to explore factors that inhibit online participation, a key issue for social movements seeking to maximize the democratic potential of ICTs (Flesher Fominaya 2016). Studies based on online participation data need, therefore, to be carefully delimited. Online participation should not be taken as a proxy or indicator of movement organization or mobilization strength, and online forms of mobilization need to be clearly distinguished from offline forms of mobilization. One illustrative example comes from the relation between Twitter use and mobilization. Much has been made of the role of Twitter in Spain's 15-M/Indignados movement (see e.g. López et al 2014), yet the 2013 data for Spain shows that Twitter users represented 15\% of the total Internet 
user population and $4 \%$ of the total population, with an average age of 22.6 for Twitter users, according to Peer Reach. ${ }^{3}$ This does not mean Twitter is irrelevant or unimportant; quite the contrary. Activists with effective communication strategies are aware of the problems caused by social media 'echo chambers' and the need to break through the social media barrier to connect to mass media outlets which will then broadcast movement messages beyond the limited Twitter-sphere. Twitter is also a crucial communication resource during intense periods of mobilization. But recognition of the limits of the Twitter-sphere and its problematic relation to offline mobilization is necessary for activists and scholars. Calls to street protest, for example, might become a trending topic on Twitter, but not yield the necessary or anticipated bodies on the street. In a similar vein, Morozov (2011) argues that activist focus on online tools can distract them from effectively engaging in those actions needed to realize significant or lasting political change (see also Dean 2009).

There is not necessarily a direct correlation, therefore, between online and offline participation, a fact that can be overlooked when all that is being measured is online participation. Selecting successful cases where intense online mobilization is accompanied by intense offline mobilization can further reinforce the idea the social media use is driving mobilization processes. As Castells argued in the midst of the hoopla around 'Twitter Revolutions' during the Arab Uprisings, 'obviously communication technologies did not give birth to the insurgency' (Castells, quoted in Khondker 2011: 678). It is obvious, but sometimes easy to forget, that 'ICTs do not cause revolutions, deep seated structural problems, mass grievances and people willing and able to act collectively do' (Flesher Fominaya 2014: 166). What is also often overlooked is how often social movement media campaigns fail to create resonance and impact in a media environment full of competing demands for attention and the continuing presence of other powerful voices with greater access to the public.

These comments highlight that while social media research is essential, one needs to be very careful in constructing research designs that rely exclusively on social media data (see also Tufekci 2014b). Attempts to represent a wider population statistically will be problematic and claims made on the basis of this data needs suitable caveats. Contentious political activity on either Twitter or Facebook is undoubtedly intrinsically interesting, but using social media as either the only source of data, or as a single starting point (e.g. providing a sampling frame of people or events) means limiting one's claims about the TMMC precisely to active users of those platforms. Fortunately, emerging scholarship in this area offers many valuable contributions to the literature, including the work of Ahmed et al., Hensby and Pavan in this issue.

It is clear that social media activity in particular, or online activity in general, is not ubiquitous in the sense that it is used by all social groups: usage is uneven in spread and heterogeneous in character. It is the case, however, that ICTs can have a different kind of ubiquity in which they are becoming present everywhere in the lives of those who engage

\footnotetext{
${ }^{3}$ For details: https://peerreach.com/
} 
with them. That is to say, while ICTs are not socially ubiquitous, they may be personally ubiquitous: for those who almost always have internet access, online services can become the first point of call for crucial information and communication tasks. This is why Liu (this issue) proposes a research programme focused on the 'politics of mundanity', in which it is recognised that explosive contentious 'moments of madness' cannot be explained without reference to the continuous presence of political online expression that has (for some groups of the population) become a constant presence in daily life. The personally ubiquitous character of ICTs is also likely to be especially important with respect to those movement groups that are most clearly intertwined with technology and the politics of cyberspace. Ganesh and Stohl (2013:425) argue that 'digital ubiquity marks the onset of a profound hybridity rather than an abrupt change in activist organizing practices'. In other words, many activists integrate new tools into existing repertoires of action, rather than radically altering their practices as a result of new technology. This is partly because as they and others have noted (Bimber et al 2012; Flesher Fominaya 2016; Lovink 2011) when technologies become so integrated into daily life as to no longer seem remarkable, people stop being as reflexive about their use. This can pose important problems for activism and scholarship on activism with regard to navigating the TMMC (Flesher Fominaya 2016). We highlight a few of these issues in the next section.

\section{Digitally enabled divides within activist communities}

Rethinking digitally enabled divides requires paying attention to the ways technology and media use can be at the centre of diverse forms of divisions within social movement communities. As Flesher Fominaya (2016) argues there is a tendency to neglect the emotional and subjective aspects of ICT use in favour of their technological aspects (i.e. costs, affordances, and leveraging). In addition, with some exceptions (e.g. Cronaeur, 2004; Horton, 2004; Pickerill, 2004; Kavada, 2007, 2009, 2010) little attention has been paid to the impact of ICTs on the internal communication and cohesion of face-to-face social movement groups. This deficit means we have insufficient knowledge of the way technology and media use is experienced subjectively by activists and how this affects social movement processes such as communication, cohesion, collective identity formation, frustration, and burnout. A key emerging area of research studies the role of digital technologies and digitally mediated communication in fostering or hindering social movement groups' ability to meet their ideological commitments to such values as democratic or horizontal participation, openness, transparency, and collaboration, goals that are often tied into the emancipatory digital imaginaries of the groups themselves (see e.g. Flesher Fominaya 2016; Hensby, this issue; Uitermark, this issue; Romanos and Sádaba 2015, Nielsen 2013).

A related issue is the role of status inequalities and power as it flows through movement spaces and is mediated by technology. Two of the key areas in this regard are the role of technological expertise, and gender. Attention to the former reveals how technological expertise can and does influence access to and control of technology and media, which can and does create important hierarchies within social movement communities, as well as affecting the closed or open nature of internal movement organizational dynamics 
(Juris et al. 2013; Pickerill 2003; Costanza-Chock 2012; Flesher Fominaya 2016). This digital divide can also intersect with other divides such as age (e.g. where older activists who may be less digitally connected or savvy feel left out when groups rely exclusively or unreflexively on technologically mediated forms of communication), gender (e.g. in hacker or radical geek spaces in which women are still minorities and face significant sexism), or economic inequality (e.g. where some members do not have constant access to the internet or mobile phones). Attention to gender reveals how it shapes patterns of mediated interaction which can marginalize, silence, delegitimize or exclude women's voices (and privilege male authority), as well as how digitally mediated interactions in cyberspace are often extremely hostile for women (and people of colour) further decreasing participation and affecting their possibilities for leadership, representation, and expression. Dahlberg (2001: 623), for example, highlights the problems stemming from a lack of reflexivity in cyber-deliberations, including the failure to achieve respectful listening or commitment to difference, the dominance of discussion by few individuals and groups, and exclusions because of social inequalities.

Perhaps due to a lingering hangover from early techno-optimism, there is still a widespread tendency to assume that the internet is somehow either inherently democratic, or else that it is a neutral autonomous sphere, despite clear evidence to the contrary. The gendered digital divide is also extremely pronounced within the communities that paradoxically offer the greatest opportunity for harnessing the power of the digital for progressive social change: the civic-technology and open source community. Not only are women woefully underrepresented in technology engineering and coding, but they are also silenced within the that community through the privileging of male voices and the value placed on male dominated roles (Maidaborn 2014). The pervasive sexism that penetrates cyber-activist spaces on and offline is clearly an area of the TMMC that needs to be reflexively and critically analysed. Reflexivity about power then, within and beyond digital activist communities, is crucial. So too is research on the ways that activists are trying to overcome these divides and maximize the potential offered by the TMMC. Understanding the ways that digital divides signal the intersection of traditional power dynamics with the dynamics of the TMMC would go a long way to rectifying some of the deficiencies in Castell's treatment of power, which we described above, as well as combating narratives that tend to flatten or neutralize power differences in virtual spaces.

\section{Conclusions}

We started this article by highlighting the interconnections between research in the fields of technology, media, and social movements, and have offered an overview of key ways these broad fields come together to provide new knowledge of social movement dynamics. But there is much more to do to understand the dynamics of the TMMC. Drawing on the conceptual clarifications and advances provided above, we now identify six broad challenges on which further attention may generate a research programme capable of transcending the current 'state of the art'. 
First, we need to pay more attention to power. On the one hand, that means more concerted focus on the political economy of media and technology in order to better understand issues of the access to, control of, and surveillance of the means by which movements are mediated. On the other, it means examining the multiple ways power imbalances 'in real life' can be reproduced, manifested, and magnified online (see e.g. Flesher Fominaya 2016) and how these traverse activist spaces and strategies, with crucial implications for participation, marginalization, inclusion, and voice.

Second, we need to pay much more attention to the lived experience of the use of digital tools. Digital mediation affects both the internal life of social movements as they communicate, deliberate, and organise, and the 'public face' of movements as they interact with broader media ecologies. Both forms of mediation are shaped by culture, emotions, gender, technological savvy, and human-technology interaction. A balanced approach to culture and material life is required to understand decisions to adopt or adapt certain forms of media and technology and to trace the way these decisions impact social movement dynamics, including cohesion, conflict, collective identity formation, and internal and external communicational and organizational strategies.

Third, we need to recognize the specificities of the media ecologies in which social movements operate, especially in local and national settings. Activists able to draw on a rich network of autonomous media resources and count on a developed critical media sphere (despite limitations posed by corporate owned mass media), for example, are likely to fare better with well-developed communicational strategies than activists who might be as technologically and politically savvy but face a harsher, less forgiving media climate. Activists' digital cultural repertoires likewise will influence the uptake or rejection of certain media technologies as much as or more than affordances.

Fourth, we need to recognize the importance of ideational frameworks and political priorities in influencing technology and media use in social movements. This means recognizing that technology itself is neither value-neutral nor value-laden, but can be harnessed by actors of all persuasions and intents. While some movement action might be driven by the excitement of novel technologies or because the manifest functionalities of those technologies fit their organisational form, others are much more embedded in the ideological commitments of activist groups, independently of the specific affordances of particular technologies.

In each of these areas, further empirical research would help us to get beyond pointing to the complexity of interactions within the TMMC, to specifying sets of cultural, material, and social conditions that in combination generate patterns of action. Doing so successfully may depend on a fifth core challenge: we need to expand and revise our methodological and ethical protocols to take into account the interpenetration of technological and social processes in so many areas of collective political action. This is in part due to the very nature of the data we are faced with analysing, which as Coleman (2010: 494) highlights, presents researchers with the challenge of how to collect and represent forms of digital data whose social and material life are often infused with elements of anonymity, modalities of hypermobility, ephemerality, and mutability'. At the 
same time we need to be critical and cautious about enthusiastic claims about the power of the internet, social media, and digital technologies when assessing causality and outcomes, as we have argued throughout. The allure of 'big data' in enabling large-scale quantitative analysis has caused considerable excitement in some parts of the social sciences, but we have expressed some caution above about the danger of reinforcing an excessively individual-centred approach to collective action. Given that access to "big data' is typically through powerful corporations or agents of state, we must also be mindful of the same kinds of ethical challenge that activists face in considering the adoption of particular tools (Gillan 2014).

Our sixth and final challenge is more theoretical in nature. The field of social movement studies has built up a set of conceptual tools that predate the digital era. We are confident most of these existing concepts are quite robust, but we should subject them to scrutiny and modification as necessary when transferring them to the TMMC. The concept of collective identity is a good example, having often been conceived as a process that requires face-to-face interaction. Despite this, re-interrogations of the concept have found that it continues to be relevant and useful even in social movements that mobilize almost entirely online, such as Anonymous (Firer-Blaess 2016, Flesher Fominaya forthcoming). We believe rising to these challenges is necessary for the further development of TMMC research, which would in turn mark a positive development for social movement scholarship as a whole.

\section{References}

Askanius, T. \& Gustafsson, N. (2010). Mainstreaming the alternative: The changing media practices of protest movements. Interface, 2(2), 23-41.

Baker, M., \& Blaagaard, B. B. (Eds.). (2016). Citizen Media and Public Spaces. London: Routledge.

Barassi, V. (2015). Social media, immediacy and the time for democracy: Critical reflections on social media as "temporalizing practices.". Critical perspectives on social media and protest: Between control and emancipation, 73-88.

Bell, D. (1974). The coming of post-industrial society : a venture in social forecasting. London: Heinemann Educational.

Benkler, Y. (2006). The wealth of networks: How social production transforms markets and freedom. New Haven: Yale University Press.

Bimber, B., Flanagin, A., \& Stohl, C. (2012). Collective action in Organizations: Interaction and engagement in an era of technological change. Cambridge, UK: Cambridge University Press.

Blanco, VFS, and JMS Duarte. (2011). Del 13-M Al 15-M. Razón Y Fe. Available at: http://www.ciber-democracia.es/articulos/SAMPEDROSANCHEZ.pdf.

Blank, G. (2016). The Digital Divide Among Twitter Users and Its Implications for Social Research. Social Science Computer Review. DOI: 10.1177/0894439316671698

Bonilla, Y. and Rosa, J. (2015). \#Ferguson: Digital protest, hashtag ethnography, and the racial politics of social media in the United States. American Ethnologist 42(1): 4-17. 
Brock, A. (2012). From the Blackhand Side: Twitter as a Cultural Conversation. Journal of Broadcasting \& Electronic Media 56(4), pp.529-549.

Boler, M. (2010). Digital Media and Democracy. Boston: MIT Press.

Brym, R., Godbout, M., Hoffbauer, A., Menard, G., \& Zhang, T. H. (2014). Social media in the 2011 Egyptian uprising. The British Journal of Sociology, 65(2), 266-292.

Cammaerts, B. (2015). Pirates on the Liquid Shores of Liberal Democracy: Movement Frames of European Pirate Parties. Javnost - The Public, 22(1), 19-36.

Carty, V. (2002). Technology and Counter-hegemonic Movements: The case of Nike Corporation. Social Movement Studies 1(2), 129.

Casero-Ripollés, A., and Ramón, A.F. (2012). Nuevas Formas de Producción de Noticias En El Entorno Digital Y Cambios En El Periodismo: El Caso Del 15-M. Comunicación Y Hombre CyH 8 (10). Universidad Francisco de Vitoria. http://ddfv.ufv.es/handle/10641/896.

Castells, M. (2015). Networks of Outrage and Hope: Social Movements in the Internet Age (Second Edition.). Cambridge, UK: Polity Press.

Castells, M. (1996). The rise of the network society. Massachusetts: Blackwell Publishers Inc.

Castells, M. (2009). Communication Power. Oxford: Oxford University Press.

Castells, M., Qiu, J. L., Fernandez-Ardevol, M., \& Sey, A. (2006). Mobile Communication and Society: A Global Perspective. Cambridge, Mass.: MIT Press.

Coleman, E. G. (2010a). The Hacker Conference: A Ritual Condensation and Celebration of a Lifeworld. Anthropological Quarterly, 83(1), 47-72.

Coleman, E. G. (2010b). Ethnographic Approaches to Digital Media. Annual Review of Anthropology, 39(1), 487-505.

Coleman, E.G. (2012). Coding Freedom: The Ethics and Aesthetics of Hacking. Princeton: Princeton University Press.

Coleman, E.G. (2015). Hacker, Hoaxer, Whistleblower, Spy: The Many Faces of Anonymous. London: Verso Books.

Chaudhuri, S., \& Fitzgerald, S. (2015). Rape Protests in India and the Birth of a New Repertoire. Social Movement Studies, 14(5), 622-628.

Chesters, G., \& Welsh, I. (2006). Complexity and social movements: multitudes at the edge of chaos. London: Routledge.

Costanza-Chock, S. (2012). Mic Check! Media Cultures and the Occupy Movement. Social Movement Studies, 11(3-4), 375-385.

Crossley, N. (2010). Towards Relational Sociology. London: Routledge.

DeLuca, M. K., \& Peeples, J. (2002). From public sphere to public screen: democracy, activism, and the "violence" of Seattle. Critical Studies in Media Communication, 19(2), 125-151.

Dencik, L., \& Leistert, O. (2015). Critical perspectives on social media and protest: Between control and emancipation. Lanham, MD: Rowman \& Littlefield International.

De Souza e Silva, A. (2006). Interfaces of Hybrid Spaces. In A. Kavoori \& N. Arceneaux (Eds.), The Cell Phone Reader. Essays in Social Transformation (pp. 19-44). Oxford: Peter Lang.

Dolata, U., \& Schrape, J.-F. (2016). Masses, Crowds, Communities, Movements: Collective Action in the Internet Age. Social Movement Studies, 15(1), 1-18.

Earl, J., \& Kimport, K. (2011). Digitally Enabled Social Change: Activism in the Internet Age. Cambridge, Massachusetts: MIT Press.

Feenberg, A. (2002). Transforming Technology: A Critical Theory Revisited (Second Edition). New York, N.Y: Oxford University Press USA.

Feenstra, R. A., \& Casero Ripollés, A. (2014). Democracy in the Digital Communication Environment: A Typology Proposal of Political Monitoring Processes. International Journal of Communication, 8, 2448-68. 
Fernandez-Planells, Ariadna, Mònica Figueras-Maz, and Carles Feixa Pàmpols. (2014). Communication among Young People in the \#spanishrevolution: Uses of Online-offline Tools to Obtain Information about the \#acampadabcn. New Media \& Society 16 (8): 12871308.

Firer-Blaess, S. (2016). The Collective Identity of Anonymous : Web of Meanings in a Digitally Enabled Movement. Uppsala: Acta Universitatis Upsaliensis: Uppsala Studies in Media and Communication 12. Available at: http://www.divaportal.org/smash/record.jsf?pid=diva2\%3A926671\&dswid=5513; accessed 12/05/2017.

Flesher Fominaya, C. (forthcoming) Collective Identity in Social Movements: Assessing the limits of a theoretical framework. In D.A. Snow, Sarah A. Soule, H. Kriesi \& H.J. McCammon (Eds.) Wiley-Blackwell Companion to Social Movements (Second Edition). Oxford: WileyBlackwell.

Flesher Fominaya, C. (2017) European Anti-Austerity and Pro-Democracy Movements in the Wake of the Global Financial Crisis. Social Movement Studies, 16 (1), 1-20.

Flesher Fominaya, C. (2016). Unintended consequences: the negative impact of e-mail use on participation and collective identity in two "horizontal" social movement groups. European Political Science Review, 8(1), 95-122.

Flesher Fominaya, C. (2015) Debunking Spontaneity: Spain's 15-M/Indignados as Autonomous Movement. Social Movement Studies, 14 (2), 142-163.

Flesher Fominaya, C. (2014). Social movements and globalization: How protests, occupations and uprisings are changing the world. Basingstoke: Palgrave Macmillan.

Freelon, D., McIlwain, C.D. and Clark, M.D. (2016). Beyond the Hashtags. \#ferguson, \#blacklivesmatter and the online struggle for offline justice. Washington, D.C.: American University Center for Media \& Social Impact. Available at: http://cmsimpact.org/wpcontent/uploads/2016/03/beyond the hashtags 2016.pdf; retrieved: 29/05/17.

Fuster Morell, M. (2012). The Free Culture and 15M Movements in Spain: Composition, Social Networks and Synergies. Social Movement Studies, 11(3-4), 386-392.

Gallo-Cruz, S. (2017). The insufficient imagery of top-down, bottom-up in global movements analysis. Social Movement Studies, 16 (2), 153-168.

Ganesh, S., \& Stohl, C. (2013). From Wall Street to Wellington: Protests in an Era of Digital Ubiquity. Communication Monographs, 80(4), 425-451.

Ganesh, S., \& Stohl, C. (2010). Qualifying Engagement: A Study of Information and Communication Technology and the Global Social Justice Movement in Aotearoa New Zealand. Communication Monographs, 77(1), 51-74.

Garton, L., \& Wellman, B. (1995). Social Impacts of Electronic Mail in Organizations: A Review of the Research Literature. Annals of the International Communication Association, 18(1), 434-453.

Gibson, R. K., Gillan, K., Greffet, F., Lee, B. J., \& Ward, S. (2013). Party organizational change and ICTs: The growth of a virtual grassroots? New Media \& Society, 15(1), 31-51.

Gillan, K. (forthcoming). Social Movements: Sequences vs. Fuzzy Temporality. In P. Kivisto (Ed.), The Cambridge Handbook of Social Theory (Vol. 2). Cambridge: Cambridge University Press.

Gillan, K. (2014, July 15). Emotional Contagion, Big Data and Research Ethics. Movements@Manchester Blog. Available at: http://www.movements.manchester.ac.uk/big-data-research-ethics/ ; accessed 7 March 2016

Gillan, K. (2008). Diverging attitudes to technology and innovation in Anti-War movement organisations. In T. Häyhtiö \& J. Rinne (Eds.), Net working/Networking: Citizen Initiated Politics. Tampere: Tampere University Press.

Gillan, K. (2009). The UK Anti-War Movement Online: Uses and Limitations of Internet 
Technologies for Contemporary Activism. Information, Communication \& Society, 12(1), 25-43.

Gillan, K., Pickerill, J., \& Webster, F. (2008). Anti-War Activism: New Media and Protest in the Information Age. Basingstoke: Palgrave Macmillan.

Gitlin, T. (2003). The Whole World Is Watching: Mass Media in the Making and Unmaking of the New Left (Second Edition.). Berkeley, CA: University of California Press.

Godwin, M. (2003). Cyber Rights: Defending Free Speech in the Digital Age (Second Edition). Cambridge, Mass: MIT Press.

Gillespie, T. (2010). The politics of "platforms." New Media \& Society, 12(3), 347-364.

Gordon, J. (2006). The Cell Phone: An Artefact of Popular Culture and a Tool of the Public Sphere. In A. Kavoori \& N. Arceneaux (Eds.), The Cell Phone Reader. Essays in Social Transformation (pp. 45-60). Oxford: Peter Lang.

Himanen, P. (2001). The Hacker Ethic: A Radical Approach to the Philosophy of Business. New York: Random House.

Hintz, A. (2015) Social Media Censorship, Privatized Regulation and New Restrictions to Protest and Dissent. In L. Dencik and O. Leistert (Eds.), Critical Perspectives on Social Media and Protest: Between Control and Emancipation. London: Rowman \& Littlefield.

Horton, D. (2004). Local Environmentalism and the Internet. Environmental Politics, 13(4), 734753.

Hwang, H., Schmierbach, M., Paek, H.-J., de Zuniga, H. G., \& Shah, D. (2006). Media Dissociation, Internet Use, and Antiwar Political Participation: A Case Study of Political Dissent and Action Against the War in Iraq. Mass Communication and Society, 9(4), 461.

Sarah J. Jackson, S.J. \& Welles, B.F. (2016). \#Ferguson is everywhere: initiators in emerging counterpublic networks. Information, Communication \& Society 19(3): 397-418.

Jordan, T. (2002). Activism! Direct Action, Hacktivism and the Future of Society. London: Reaktion.

Jordan, T., \& Taylor, P. A. (2004). Hacktivism and Cyberwars: Rebels with a Cause. London: Routledge.

Jordan, T. (2013) Information as politics. Culture Machine, 14: 1-22.

Jordan, T. (2015). Information politics: liberation and exploitation in the digital society. London: Pluto.

Juris, J. S. (2008). Networking Futures: The Movements Against Corporate Globalization. Durham, NC: Duke University Press.

Juris, J. S., Caruso, G., Couture, S., \& Mosca, L. (2013). The Cultural Politics of Free Software and Technology within the Social Forum Process. In J. S. Juris \& A. Khasnabish (Eds.), Insurgent Encounters: Transnational Activism, Ethnography, and the Political (pp. 342-65). Durham, NC: Duke University Press.

Kavada, A. (2016). Social Movements and Political Agency in the Digital Age: A Communication Approach. Media and Communication, 4(4), 8-12.

Kavada, A. (2015). Creating the collective: social media, the Occupy Movement and its constitution as a collective actor. Information, Communication \& Society, 18(8), 872-886.

Kavada, A. (2009). Email Lists and the Construction of an Open and Multifaceted Identity. Information, Communication \& Society, 12(6), 817-839.

Kiesler, S., \& Sproull, L. (1992). Group decision making and communication technology. Organizational Behavior and Human Decision Processes, 52(1), 96-123.

Kirkpatrick, G. (2008). Technology and social power. Basingstoke: Palgrave Macmillan.

Leruth, B. (2016, October 31). Iceland's election: the Pirates failed to live up to expectations, but this was still a landmark result. LSE European Politics and Policy (EUROPP) Blog. Available at: http://blogs.lse.ac.uk/europpblog/; accessed 15 May 2017. 
Lessig, L. (2002). The Future of Ideas: The Fate of the Commons in a Connected World. New York: Vintage.

Lovink, G. (2012). Networks without a Cause: A Critique of Social Media. Cambridge: Polity Press.

McCarthy, J. D., Smith, J., Zald, M. N. (1996). Accessing Public, Media, Electoral and Governmental Agendas. In D. McAdam, J. D. McCarthy, \& M. N. Zald (Eds.), Comparative Perspectives on Social Movements. Political Opportunities, Mobilizing Structures and Cultural Framings. (pp. 291-311). Cambridge University Press, Cambridge.

Maidaborn, Vivien. 2014. Open Sourcing Feminism: The Challenge of Collective Intelligence in 2014. Loomio Blog. Available at: http://blog.loomio.org/2014/03/08/open-sourcingfeminism-the-challenge-of-collective-intelligence-in-2014/.

Mattoni, A. (2012). Media Practices and Protest Politics: How Precarious Workers Mobilise. Farnham: Ashgate Publishing.

Melucci, A. (1994). A strange kind of newness: What's 'new' in new social movements? In EnriqueLaraña, Hank Johnston, \& Joseph R. Gusfield (Eds.), New social movements: From ideology to identity (pp. 103-130). Philadelphia, PA: Temple University Press.

Mercea, D. and Yilmaz, K.E. (forthcoming). Movement Social Learning on Twitter: The Case of the People's Assembly. The Sociological Review. Available at: https://ssrn.com/abstract=2971253; retrieved: 29/05/2017.

Milan, S. (2013). Social Movements and Their Technologies: Wiring Social Change. Palgrave Macmillan.

Milan, S. (2015). From social movements to cloud protesting: the evolution of collective identity. Information, Communication \& Society, 18(8), 887-900.

Monterde, A. and J. Postill 2014. Mobile ensembles: The uses of mobile phones for social protest by Spain's indignados. In G. Goggin and L. Hjorth (eds.) Routledge Companion to Mobile Media. London: Routledge.

Nielsen, R. K. (2011). Mundane internet tools, mobilizing practices, and the coproduction of citizenship in political campaigns. New Media \& Society, 13(5), 755-771.

Nielsen, R. K. (2013). Mundane Internet Tools, the Risk of Exclusion, and Reflexive MovementsOccupy Wall Street and Political Uses of Digital Networked Technologies. The Sociological Quarterly, 54(2), 173-177.

Oddsdóttir, K. (2014). Iceland: The Birth of the World's First Crowd-Sourced Constitution. Cambridge Journal of International and Comparative Law, 3, 1207-1220.

Ofcom. (2016). Adults' Media Use and Attitudes. London: Ofcom. Available at: https://www.ofcom.org.uk/ data/assets/pdf file/0026/80828/2016-adults-media-useand-attitudes.pdf; accessed 23/04/2017.

Oliver, P. E., \& Maney, G. M. (2000). Political Processes and Local Newspaper Coverage of Protest Events: From Selection Bias to Triadic Interactions. American Journal of Sociology, 106(2), 463-505.

Olson, M. (1965). The Logic of Collective Action: Public Goods and the Theory of Groups. Harvard, MA.: Harvard University Press.

Pickerill, J. (2003). Cyberprotest: Environmental Activism Online. Manchester: Manchester UniversityPress.

Pickerill, J. (2004). Rethinking Political Participation: Experiments in Internet Activism in Australia and Britain. In R. Gibson, A, Rommele and S. Ward (Eds) Electronic Democracy: Mobilisation, Organisation and Participation Via New ICTs (pp. 170-93). London: Routledge.

Pickerill, J. (2007). Autonomy online: Indymedia and practices of alter-globalisation. Environment and Planning A, 39, 2668-2684.

Pleyers, G. (2011). Alter-Globalization: Becoming Actors in the Global Age. Cambridge: Polity Press. 
Postill, J. (2014). Freedom technologists and the new protest movements: A theory of protest formulas. Convergence, 20(4), 402-418.

Powell, A. (2016). Hacking in the public interest: Authority, legitimacy, means, and ends. New Media \& Society, 18(4), 600-616.

Redshaw, T. (2017). Bitcoin beyond ambivalence: Popular rationalization and Feenberg's technical politics. Thesis Eleven, 138(1), 46-64.

Rheingold, H. (1993). The Virtual Community. Boston: Addison Wesley.

Rheingold, H. (2003). Smart Mobs: The Next Social Revolution. New York: Perseus Books.

Romanos, Eduardo, and Igor Sádaba. (2015). La Evolución de Los Marcos (Tecno) Discursivos Del Movimiento 15M Y Sus Consecuencias. Empiria. Revista de Metodología de Ciencias Sociales 32: 15-36.

Ryan, C. (1991). Prime Time Activism: Media Strategies for Grassroots Organizing. South End Press.

Shirky, C. (2009). Here comes everybody: How change happens when people come together. London: Penguin UK.

Siapera, E. (2011). Understanding New Media. Thousand Oaks, CA: Sage Publications Ltd.

Smith, J., McCarthy, J. D., McPhail, C., \& Augustyn, B. (2001). From Protest to Agenda Building: Description Bias in Media Coverage of Protest Events in Washington, D.C. Social Forces, 79(4), 1397-1423.

Stalder, F. (2010). Digital Commons. In K. Hart, J.-L. Laville, \& A. D. Cattani (Eds.), Human Economy: A Citizen's Guide (pp. 313-325). Cambridge: Polity Press.

Stoycheff and Nisbet (2016) "Is Internet Freedom a tool for democracy or authroitarianism? “ The Conversation. Retrieved https://theconversation.com/is-internet-freedom-a-tool-fordemocracy-or-authoritarianism-61956)

Subirats, J, M Fuster, R Martínez, and M Berlinguer. 2014. “Jóvenes, Internet Y Política." http://ictlogy.net/bibliography/reports/projects.php?idp=2691\&lang=ca.

Tufekci, Z. (2014a). The Medium and the Movement: Digital Tools, Social Movement Politics, and the End of the Free Rider Problem. Policy \& Internet, 6(2), 202-208.

Tufekci, Z. (2014b). Big Questions for Social Media Big Data: Representativeness, Validity and Other Methodological Pitfalls. In ICWSM '14: Proceedings of the 8th International AAAI Conference on Weblogs and Social Media, 2014.

Tufekci, Z. (2015). Algorithmic Harms beyond Facebook and Google: Emergent Challenges of Computational Agency. Colorado Technology Law Journal, 13, 203-217.

Tufekci, Z., \& Wilson, C. (2012). Social Media and the Decision to Participate in Political Protest: Observations From Tahrir Square. Journal of Communication, 62(2), 363-379.

Vromen, A. (2015). Campaign Entrepreneurs in Online Collective Action: GetUp! in Australia. Social Movement Studies, 14(2), 195-213.

Wall, M. A. (2007). Social movements and email: expressions of online identity in the globalization protests. New Media \& Society, 9(2), 258-277.

Wolfson, T. (2014). Digital Rebellion: The Birth of the Cyber Left. Urbana: University of Illinois Press. 